РАДІОБІОЛОГІЯ ТА РАДІОЕКОЛОГІЯ

RADIOBIOLOGY AND RADIOECOLOGY

\author{
A. Yu. Lonin*, V. V. Levenets, O. P. Omelnik, A. O. Shchur \\ National Science Center "Kharkov Institute of Physics \& Technology", Kharkiv, Ukraine \\ *Corresponding author: a_lonin@kipt.kharkov.ua

\section{USE OF MATHEMATICAL MODELING FOR COMPARATIVE EVALUATION OF SORPTION CAPACITY OF NATURAL AND SYNTHETIC ZEOLITES IN RELATION TO CESIUM}

\begin{abstract}
The comparison of sorption capacity of clinoptilolite and synthetic zeolites (zeolite $\mathrm{NaX}$ and zeolite $\mathrm{NaA}$ ) in relation to the cesium in dynamic conditions was conducted. Dynamic conditions include multiple circulation of cesium containing solution through the sorbent layer. The mathematical modeling of sorption isotherms using the Langmuir equation, the Chebyshev criterion, and the least-squares method was conducted. Correlation of actual and model results indicates that the considered models adequately reflect sorption processes occurring in zeolites. The results of the study make it possible to use the considered models for predicting the behavior of zeolites in relation to cesium.

Keywords: zeolites, cesium, dynamic sorption, mathematical modeling.
\end{abstract}

\section{Introduction}

According to the data of IAEA published in 2015 , there are 438 operating nuclear reactors in the world. The total generating capacity of the NPP is 376.2 GW. Considering the consequences of the accident at the Japanese nuclear power plant "Fukushima-1", IAEA made a significant adjustment to plans for the development of nuclear power in the world for the period up to 2030. Thus, the growth of nuclear power capacity can range from 8 to $88 \%$ [1]. This is due to the fact that a number of countries have already refused, or are planning to abandon the use of nuclear energy. These countries include Italy, Austria, Belgium and Germany. Nevertheless, at the beginning of 2015, construction of 70 reactors was conducted $[1,2]$.

The operation and construction of nuclear power plants is associated with a number of problems. One of the important problems restraining the development of nuclear power is the increase in the volumes of radioactive waste and the complexity of their disposal. It should be noted that the amount and type of generated waste are directly related to the type of reactor and the period of its operation. During the operation of the reactor, different types of radioactive waste are generated, which the IAEA classifies as: low-active, medium-active and highly active. Depending on the physical state of radioactive waste, they are divided into liquid (LRW) and solid (SRW). A large amount of LRW is formed at the nuclear power plant. With the creation of 1 billion $\mathrm{kWh}$ at the NPP, $27 \mathrm{~m}^{3}$ of SRW and $35.1 \mathrm{~m}^{3}$ of LRW are formed. LRW includes lowlevel and medium-level waste. According to their radionuclide composition, LRW includes ${ }^{137} \mathrm{Cs}$,
${ }^{134} \mathrm{Cs},{ }^{90} \mathrm{Sr},{ }^{226} \mathrm{Ra},{ }^{60} \mathrm{Co}$ [3]. To store the radioactive generated waste, special storage facilities and disposal facilities are needed. At the beginning of 2015, 467 radioactive waste storage facilities and 145 radioactive waste disposal sites were located in the world [1].

For the further disposal and recycling of LRW it is necessary to carry out additional purification and concentration of radioactive isotopes. One method of removal of radionuclides from solutions is the use of sorbents. The aim of our research was zeolites, which occupy a special place among sorbents. A feature of zeolites is the presence of two sorption mechanisms in their interaction with radionuclides: adsorption and ion sorption. For the research, synthetic zeolites and natural zeolites of mineral origin are used. This leads to the fact that one and the same mineral depending on the place of extraction can have a different elemental composition while maintaining the crystal structure. The exchange ions, which directly affect the change in the sorption properties of the zeolite, are subjugated to the main changes. As a result, various modifications of one mineral are formed. According to the data of the American Mineralogical Society, there are 17 modifications of clinoptilolite [4].

The sorption of cesium by zeolites (natural clinoptilolite and synthetic - zeolite $\mathrm{NaX}$ and zeolite $\mathrm{NaA}$ ) under dynamic conditions has been described in the works published earlier by us $[5,6]$. Dynamic conditions include multiple circulation of cesium containing solution through the sorbent layer. When processing the results for the quantitative characterrization of sorption, the sorption coefficient was used. The sorption coefficient (Ks, \%) was calculated by the formula: 


$$
K_{s}=\frac{\left(C_{0}-C_{p}\right) \cdot 100 \%}{C_{0}},
$$

where $C_{0}$ and $C_{p}$ are the initial and equilibrium concentrations of the solution, $\mathrm{mol} / \mathrm{dm}^{3}$.

The sorption coefficient is a relative indicator and does not allow to obtain a complete objective assessment of sorption abilities of zeolites. Therefore, it is expedient to make a quantitative evaluation of the sorption properties of zeolites using the exchange capacity. The use of exchange capacity allows to perform of mathematical modeling of sorption processes with the Langmuir equation.
The aim of this study was to compare the sorption capacity of natural and synthetic zeolites (clinoptilolite and synthetic zeolite $\mathrm{NaX}$ and zeolite $\mathrm{NaA}$ ) in relation to the cesium and the construction of mathematical models that make it possible to characterize data of sorption processes. When carrying out a comparative evaluation of the sorption properties of zeolites, it is necessary to take into account the influence of the $\mathrm{Si} / \mathrm{Al}$ ratio on the exchange capacity of zeolites, which is confirmed by the materials presented in the Table $1[7,8]$.

Table 1. Dependence of exchange properties of zeolites on the ratio $\mathrm{Si} / \mathrm{Al}[7,8]$

\begin{tabular}{|c|c|c|c|c|}
\hline Zeolite & $\begin{array}{c}\text { The ratio } \\
\mathrm{Si} / \mathrm{Al}\end{array}$ & $\begin{array}{c}\text { The exchange constant } \\
\mathrm{Na}^{+} \rightarrow \mathrm{Cs}^{+}\end{array}$ & $\begin{array}{c}\text { Exchange capacity } \mathrm{Cs}^{+}, \\
\mathrm{mol} / \mathrm{kg}\end{array}$ & $\begin{array}{c}\text { Maximum exchange } \\
\text { capacity, } \mathrm{mol} / \mathrm{kg}\end{array}$ \\
\hline Clinoptilolite & $4.25-5.25$ & 63.0 & 0.60 & 2.2 \\
\hline Zeolite $\mathrm{NaX}$ & $1.00-1.50$ & 31.6 & 0.65 & 4.7 \\
\hline Zeolite $\mathrm{NaA}$ & $0.70-1.20$ & - & 0.45 & 5.5 \\
\hline
\end{tabular}

\section{Methods and objects of research}

\subsection{Objects of research}

During the research, natural zeolite-clinoptilolite $\left((\mathrm{K}, \mathrm{Na}, \mathrm{Ca})_{2} \times \mathrm{Al}_{2} \mathrm{Si}_{7} \mathrm{O}_{18} \times 6 \mathrm{H}_{2} \mathrm{O}\right)$ and synthetic zeolites $(\mathrm{NaX}, \mathrm{NaA})$ were used.

\subsection{Dynamic cesium sorption}

For the experiments, an aqueous solution of cesium nitrate $-\mathrm{CsNO}_{3}$ was used. The concentration of $\mathrm{CsNO}_{3}$ solution is $500.0 \mathrm{mg} / \mathrm{L}$. The volume of the solution for pumping through the plant was $500 \mathrm{ml}$. For modeling of dynamic conditions of sorption was used installation (Fig. 1) [5]. The installation consists of: pump, sorption column with cartridge, reservoir, measuring tank. Dimensions of the sorption cartridge: diameter $8 \mathrm{~mm}$, height $25 \mathrm{~mm}$. The mass of zeolites placed in the sorption plant was $2.0 \mathrm{~g}$. The flow rate was $4 \mathrm{~L} / \mathrm{h}$.

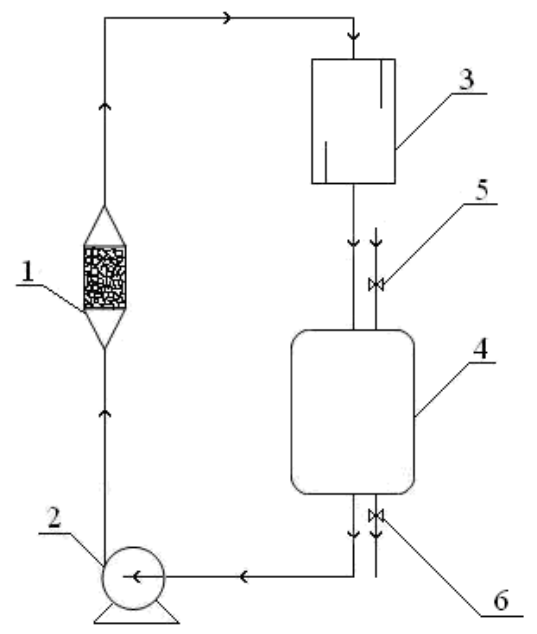

Fig. 1. [5] Sorption installation scheme: 1 - sorption column; 2 - pump; 3 - measuring tank; 4 - reservoir-collection; 5, 6 - supply and discharge valves, respectively.
The determinations of dynamic sorption were carried out at a constant temperature $\mathrm{t}=24^{\circ} \mathrm{C}$.

\subsection{Quantitative determination of cesium}

The analytical part of the work was carried out on the analytical nuclear-physical complex "Sokol". The targets from a dry residue of a solution on a carbon substrate were used for measurements. Activation of cesium was carried out by a beam of protons with energy Ep $\approx 1600 \mathrm{keV}$, average current $\mathrm{Ir} \approx 150 \mathrm{nA}$. Registration of the excited characteristic X-ray emission of L-series cesium atoms was carried out using a $\mathrm{Si}$-pin detector with a resolution of $155 \mathrm{eV}$ by line $6.4 \mathrm{keV}$. The detector was placed at a distance of $7 \mathrm{~cm}$ from the target, at an angle of $135^{\circ}$ to the proton beam. The Si-pin detector was equipped with a collimator $\varnothing 2.5 \mathrm{~mm}$ and a polyvinylchloride absorber $150 \mu \mathrm{m}$ thick. The relative error of the measurements was $5 \%[5,6]$.

\section{Results and discussion}

As a quantitative characteristic of the interaction of sorbents with cesium, the amount of adsorption of zeolites $\left(\mathrm{q}_{\mathrm{c}}, \mathrm{mg} / \mathrm{g}\right)$ was used:

$$
q_{c}=\frac{\left(C_{0}-C_{p}\right) \cdot V}{m},
$$

where $C_{0}$ and $C_{p}$ are the initial and equilibrium concentrations of the solution, $\mathrm{mg} / \mathrm{L} ; V$ - volume of solution passed through the installation, $\mathrm{ml} ; m$ mass of sorbent, $\mathrm{g}$.

The determination of the equilibrium concentration was carried out experimentally in the course of sorption. The cesium content was determined according to the procedure given above. The equilibrium concentration of cesium for zeolites is shown in Table 2. 
Table 2. The values of the equilibrium concentration of cesium for zeolites in dynamic conditions

\begin{tabular}{|c|c|c|c|}
\hline \multirow{2}{*}{ Sorption cycle } & \multicolumn{3}{|c|}{ The equilibrium concentration of cesium, $\mathrm{mg} / \mathrm{L}$} \\
\cline { 2 - 4 } & clinoptilolite & zeolite $\mathrm{NaX}$ & zeolite NaA \\
\hline 5 & 56.0 & 68.0 & 28.0 \\
\hline 10 & 347.7 & 201.3 & 62.7 \\
\hline 15 & 355.5 & 201.3 & 66.0 \\
\hline 20 & 401.5 & 205.4 & 66.2 \\
\hline 30 & 423.3 & 214.7 & 194.5 \\
\hline 40 & 425.0 & 254.9 & 197.0 \\
\hline
\end{tabular}

The obtained values of the sorption capacity of zeolites to cesium, depending on the sorption cycle, are presented in Table 3.

Table 3. Sorption capacity of zeolites in relation to cesium in dynamic conditions

\begin{tabular}{|c|c|c|c|}
\hline Sorption cycle & \multicolumn{3}{|c|}{$\mathrm{q}_{\mathrm{c}}, \mathrm{mg} / \mathrm{g}$} \\
\hline & Clinoptilolite & Zeolite NaX & Zeolite NaA \\
\hline 5 & 83.5 & 103.5 & 46.75 \\
\hline 10 & 200.0 & 119.5 & 93.5 \\
\hline 15 & 204.5 & 119.5 & 97.75 \\
\hline 20 & 231.0 & 121.5 & 100.75 \\
\hline 30 & 243.5 & 127.0 & 114.75 \\
\hline 40 & 244.5 & 134.5 & 116.25 \\
\hline
\end{tabular}

On the basis of the obtained results, it can be asserted that the saturation of the sorption capacity of zeolites to cesium consists of two phases: fast and slow.

For clinoptilolite and zeolite $\mathrm{NaA}$, the fast phase of saturation of the sorption capacity makes the first 10 cycles of purification. For zeolite $\mathrm{NaX}$, the fast phase of saturation of the sorption capacity makes the first 5 cycles of purification. The slow phase lasts from 30 to 35 cycles of purification, respectively. Taking into account the obtained results, it can be stated that clinoptilolite is the most effective of the three considered zeolites. The clinoptilolite after 40 cycles of sorption has a sorption capacity of $244.5 \mathrm{mg} / \mathrm{g}$, which exceeds the sorption capacity for synthetic zeolites by almost two times.

For a comparative analysis of the sorption capacity of zeolites in relation to cesium actual results with mathematical model data were compared. Adsorption is a process of spontaneous redistribution of system components between the surface layer of the sorbent and the liquid phase. The adsorption process is expressed by an isotherm characterized by a functional dependence of the amount of the surface adsorbed from the pressure or concentration of this substance in another phase at a constant temperature. There is no unified theory that describes all types of adsorption processes. To describe adsorption processes, the theories of Langmuir, Polyanin, and Dubinin are used. The most reliably models the adsorption processes of the
Langmuir isotherm taking into account the sorption properties of zeolites and their interaction with the liquid phase.

The Langmuir isotherm model is applied to monolayer adsorption. This model assumes that the adsorbate ions are evenly distributed between the adsorption centers. The Langmuir model is based on the following provisions:

adsorption is localized in certain centers and is caused by chemical forces;

adsorption does not occur on the entire surface of the adsorbent, but in certain active centers that are characterized by the presence of free valences;

each active center is only able to interact with one molecule of adsorbat and on the surface of the adsorbent, only one layer of adsorbed molecules can be formed $[9,10]$.

The Langmuir model is described by the equation

$$
q_{e}=q_{m} \frac{K \cdot C}{1+K \cdot C},
$$

where $q_{e}$ is the equilibrium amount of adsorption, $\mathrm{mg} / \mathrm{g} ; C$ - equilibrium concentration in solution, $\mathrm{mg} / \mathrm{L} ; K$ - Langmuir constant, L/mg; $q_{m}$ - maximum adsorption capacity, $\mathrm{mg} / \mathrm{g}$.

Langmuir model for monolayer sorption allows to assess the sorption properties of sorbents with a uniform surface. To determine $q_{m}$ and $K$, the Langmuir equation leads to a linear form. The linear form of the Langmuir equation is expressed by the following formula: 


$$
\frac{1}{q_{e}}=\frac{1}{q_{m}}+\frac{1}{q_{m} \cdot K \cdot C} .
$$

To evaluate the reliability of the obtained results, mathematical modeling based on the principle of best approximation was used. The mathematical modeling allows to determine the criteria for agreement. The most common are the following criteria: least square method; Chebyshev's criterion.

The criterion of the method of least squares allows one to obtain a smoothing of the curve, provides an opportunity to separate data, which do not require additional information about interference.

The Chebyshev criterion - reduces the extreme maximum error. The Chebyshev criterion is used when it is necessary to avoid large errors when approximating.

In our studies, both criteria were used, which were calculated as follows.

The criterion of the method of least squares involves minimizing the sum of error squares at the node points:

$$
J=\sum_{i=1}^{n}\left(F\left(x_{i}\right)-y_{i}\right)^{2},
$$

where $y_{i}$ is the value of the initial function at the point $x_{i}$ (tabular value); $F\left(x_{i}\right)$ is the value of the approximating function.

The minimal Chebyshev criterion is determined by the formula

$$
J=\max \left|F\left(x_{i}\right)-y_{i}\right|,
$$

where $y_{i}$ is the value of the initial function at the point $x_{i}$ (tabular value); $F\left(x_{i}\right)$ is the value of the approximating function.

The calculation of the constants using the Langmuir equation, the Chebyshev criterion, and the least-squares test was carried out using the computer program "Langmuir", which is freely available.

The results obtained for all zeolites considered in the work are presented below (Tables 4 - 6, Figs. 2 - 4).

\section{Table 4. Sorption capacity of clinoptilolite

\begin{tabular}{|c|c|c|c|}
\hline 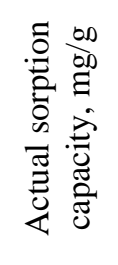 & 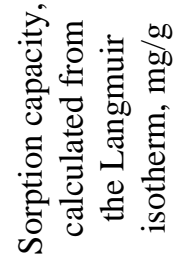 & 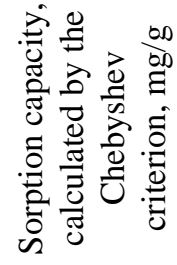 & 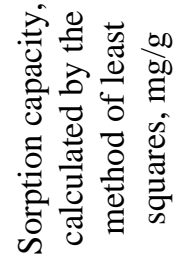 \\
\hline 83.5 & 83.5 & 83.5 & 82.1 \\
\hline 204.5 & 223.1 & 223.1 & 227.7 \\
\hline 244.5 & 227.7 & 229.0 & 230.3 \\
\hline
\end{tabular} in relation to the cesium (according to the Langmuir program)}

Table 5. Sorption capacity of $\mathrm{NaX}$ zeolite

\begin{tabular}{|c|c|c|c|}
\hline 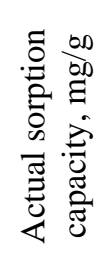 & 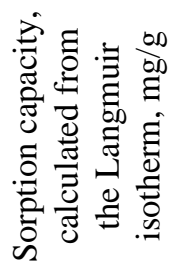 & 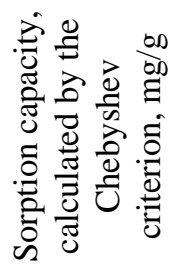 & 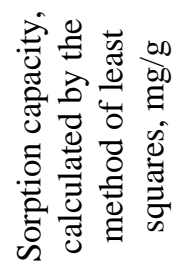 \\
\hline 103.5 & 102.3 & 102.3 & 101.6 \\
\hline 119.5 & 121.6 & 121.6 & 122.3 \\
\hline 134.5 & 129.6 & 129.6 & 130.3 \\
\hline
\end{tabular}
in relation to the cesium (according to the "Langmuir" program)

Table 6. Sorption capacity of NaA zeolite

\begin{tabular}{|c|c|c|c|}
\hline 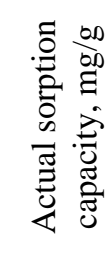 & 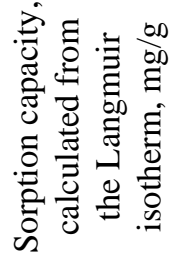 & 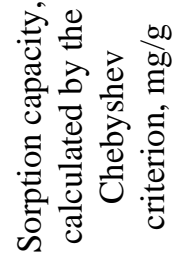 & 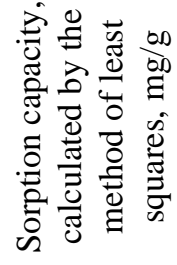 \\
\hline 46.75 & 46.75 & 46.75 & 51.02 \\
\hline 97.75 & 89.21 & 88.49 & 89.92 \\
\hline 116.25 & 126.93 & 125.51 & 119.13 \\
\hline
\end{tabular}
in relation to the cesium

(according to the "Langmuir" program)

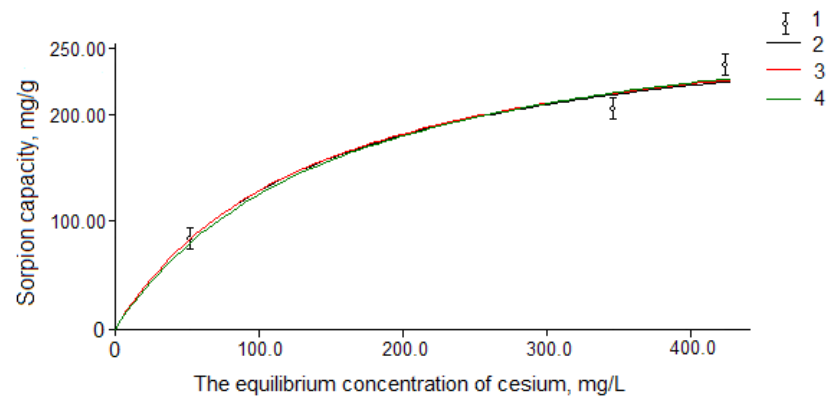

Fig. 2. Isotherms of cesium sorption by clinoptilolite: 1 - actual results with allowable deviation interval; 2 isotherm by the Langmuir curve; 3 - isotherm constructed according to the Chebyshev criterion; 4 -isotherm constructed by the method of least squares.

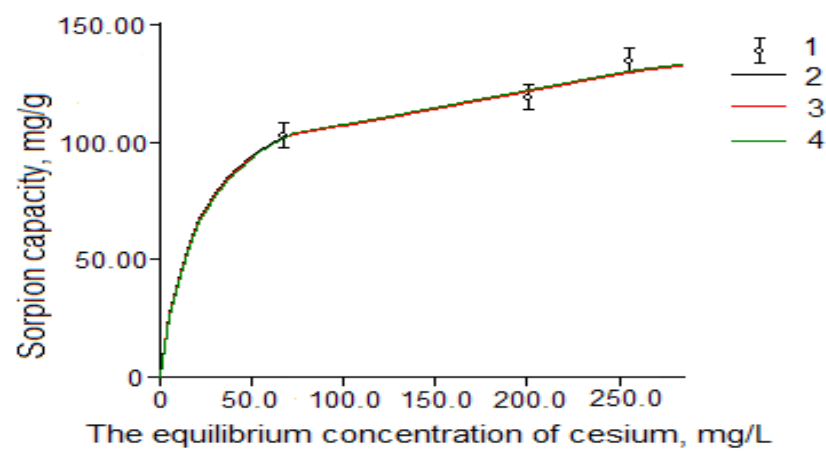

Fig. 3. Isotherms of cesium sorption by zeolite NaX: 1 - actual results with allowable deviation interval; 2 isotherm by the Langmuir curve; 3 - isotherm constructed according to the Chebyshev criterion; 4 -isotherm constructed by the method of least squares. 


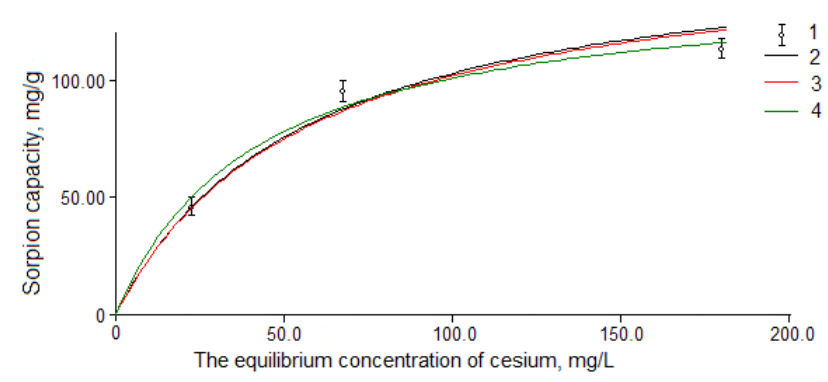

Fig. 4. Isotherms of cesium sorption by zeolite $\mathrm{NaA}$ : 1 - actual results with allowable deviation interval; 2 isotherm by the Langmuir curve; 3 - isotherm constructed according to the Chebyshev criterion; 4 -isotherm constructed by the method of least squares.

The obtained results on the basis of the Langmuir equation, and also with the Chebyshev criterion and the least squares test, can be compared with the experimentally obtained results and the determination of the linear correlation coefficient for each of the sorbents. The correlation coefficient makes it possible to determine the linear relationship in the pair represented by the actual results and the calculated data obtained. The correlation coefficient was calculated by the formula

$$
R_{X, Y}=\frac{\sum_{i=1}^{m}\left(X_{i}-\bar{X}\right)\left(Y_{i}-\bar{Y}\right)}{\sqrt{\sum_{i=1}^{m}\left(X_{i}-\bar{X}\right)^{2} \sum_{i=1}^{m}\left(Y_{i}-\bar{Y}\right)^{2}}},
$$

where, $\bar{X}, \bar{Y}$ - sample mean values; $X_{m}$ (results of actual zeolite sorption) and $Y_{m}$ (model values of zeolite sorption).

When considering the correlation coefficient, it is necessary to take into account that the closer the value of the coefficient to 1 , then the greater the functional connections in the considered pair of actual and model results. If the value of the coefficient is closer to 0 , then the connection is weak or absent. The results of determining the correlation coefficient are presented in Table 7.

The calculated correlation coefficients are close to 1 (for the clinoptilolite the correlation coefficient is 0.9747 to 0.9790 , for the zeolite $\mathrm{NaX} 0.9753$ to 0.9786 , for the zeolite NaA 0.9738 to 0.9835 ). This indicates that the models considered allow to give an adequate estimate of the cesium sorption by the zeolites examined.

\section{Table 7. The determination of the correlation coefficient for the considered sorbents, the actual results of cesium sorption and mathematical models}

\begin{tabular}{|c|c|c|c|}
\hline \multirow{2}{*}{$\begin{array}{c}\text { Mathematical } \\
\text { models }\end{array}$} & clinoptilolite & $\begin{array}{c}\text { zeolite } \\
\text { NaX }\end{array}$ & $\begin{array}{c}\text { zeolite } \\
\text { NaA }\end{array}$ \\
\cline { 2 - 4 } & 0.9774 & 0.9786 & 0.9738 \\
\hline $\begin{array}{c}\text { Langmuir } \\
\text { isotherm }\end{array}$ & 0.9790 & 0.9786 & 0.9739 \\
\hline $\begin{array}{c}\text { Chebyshev } \\
\text { criterion }\end{array}$ & 0.9747 & 0.9753 & 0.9835 \\
\hline $\begin{array}{c}\text { The criterion of } \\
\text { the method of } \\
\text { least squares }\end{array}$ & & & \\
\hline
\end{tabular}

The experimental and mathematical obtained data confirm the high sorption properties of clinoptilolite, which can be recommended for later self-use in nuclear power engineering for LRW purification.

The sorption capacity of clinoptilolite in relation to cesium was $244.5 \mathrm{mg} / \mathrm{g}$, which exceeds the sorption capacity of synthetic zeolites twice.

It should be borne in mind that Ukraine has large reserves of clinoptilolite.

\section{Conclusions}

When comparing the sorption capacity of clinoptilolite and synthetic zeolites (zeolite $\mathrm{NaX}$ and zeolite $\mathrm{NaA}$ ) in relation to cesium in dynamic conditions, it has been established that clinoptilolite $\left(\mathrm{q}_{\mathrm{c}}=244.5 \mathrm{mg} / \mathrm{g}\right)$ has the greatest sorption capacity in relation to cesium, which exceeds the sorption capacity of synthetic zeolites twice.

Using the "Langmuir" program of simulating cesium sorption isotherms by zeolites in accordance with the Langmuir equation, the Chebyshev criterion and the least-squares test confirmed the experimental values of the sorption capacity. Correlation of the results indicates the correct choice of mathematical models.

The obtained results determine the possibility of independent use of clinoptilolite in nuclear power engineering for decontamination of LRW.

\section{REFERENCES}

1. Nuclear Technology Review 2015 (report by the IAEA Director General). IAEA, 2015.

2. The Baltic Course. News and analytics (10.11.2015).

3. N.P. Chernikov, L.I. Lukin. Problems of handling spent ion-exchange resins of nuclear power plants and possible ways to solve them. Zbirnyk Naukovykh Prats' SNUYaE\&P (Sevastopol: SNUYa\&P) 34 (2010) 127. (Rus)
4. American Mineralogist Crystal Structure Database.

5. A.Yu. Lonin, V.V. Levenets, I.M. Neklyudov, A.O. Shchur. The usage of zeolites for dynamic sorption of cesium from waste waters of nuclear power plants. Journal of Radioanalytical and Nuclear Chemistry 303 (2015) 831.

6. V.V. Levenets, A.Yu. Lonin, O.P. Omelnik, A.O. Shchur. PIXE in the studies of stable cesium 
sorption from water solutions. X-Ray Spectrometry 44 (2015) 447.

7. Ch. Amflet. Inorganic Ion Exchangers (Moskva: Mir, 1966) 188 p. (Rus)

8. Yu.I. Tarasevich. Natural Sorbents in Processes of Water Purification (K.: Naukova Dumka, 1981) 208 p. (Rus)
9. V.V. Venetsianov, N.N. Rubinstein. Dynamics of Sorption from Liquid Media (Moskva: Nauka, 1983) 238 p. (Rus)

10. V.G. Matveykin, V.A. Pogonin, S.B. Putin, S.A. Skvortsov. Mathematical Modeling and Control of the Short-Cycle Adsorption Process (Moskva: Mashinostroenie-1, 2007) 140 p. (Rus)

О. Ю. Лонін*, В. В. Левенець, О. П. Омельник, А. О. Щур

Національний науковий цฺентр «Харківський фізико-технічний інститут», Харків, Украӥна

*Відповідальний автор: a_lonin@kipt.kharkov.ua

\section{ВИКОРИСТАННЯ МАТЕМАТИЧНОГО МОДЕЛЮВАННЯ ДЛЯ ПОРІВНЯЛЬНОЇ ОЦІНКИ СОРБЦЙНОЇ ЄМНОСТІ ПРИРОДНОГО І СИНТЕТИЧНИХ ЦЕОЛІТІВ ЩОДО ЦЕЗІЮ}

Проводилося порівняння сорбційної ємності кліноптілоліту і синтетичних цеолітів (цеоліт NaX i цеоліт $\mathrm{NaA}$ ) по відношенню до цезію в динамічних умовах. Динамічні умови передбачають багаторазову циркуляцію розчину, що містить цезій через шар сорбенту. Проведено математичне моделювання сорбційних ізотерм із використанням рівняння Ленгмюра, критерію Чебишева та критерію методу найменших квадратів. Кореляція фактичних і модельних результатів свідчить про те, що розглянуті моделі адекватно відображають сорбційні процеси, що проходять у цеолітах. Це дає можливість використовувати розглянуті моделі для прогнозування взаємодії цеолітів із цезієм.

Ключові слова: цеоліти, цезій, динамічна сорбція, математичне моделювання.

А. Ю. Лонин*, В. В. Левенец, А. П. Омельник, А. А. Щур

Нацииональный научный центр «Харьковский физико-технический институт», Харьков. Украина

*Ответственный автор: a_lonin@kipt.kharkov.ua

\section{ИСПОЛЬЗОВАНИЕ МАТЕМАТИЧЕСКОГО МОДЕЛИРОВАНИЯ ДЛЯ СРАВНИТЕЛЬНОЙ ОЦЕНКИ СОРБЦИОННОЙ ЕМКОСТИ ПРИРОДНОГО И СИНТЕТИЧЕСКИХ ЦЕОЛИТОВ В ОТНОШЕНИИ ЦЕЗИЯ}

Проводилось сравнение сорбционной емкости клиноптилолита и синтетических цеолитов (цеолит NaX и цеолит $\mathrm{NaA}$ ) по отношению к цезию в динамических условиях. Динамические условия предусматривают многократную циркуляцию раствора, содержащего цезий через слой сорбента. Проведено математическое моделирование сорбционных изотерм с использованием уравнения Ленгмюра, критерия Чебышева и критерия метода наименьших квадратов. Корреляция фактических и модельных результатов свидетельствует о том, что рассмотренные модели адекватно отображают сорбционные процессы, проходящие в цеолитах, что дает возможность использовать рассмотренные модели для прогнозирования поведения цеолитов в отношении цезия.

Ключевые слова: цеолиты, цезий, динамическая сорбция, математическое моделирование.

Надійшла 30.10.2017

Received 30.10.2017 